\title{
U.S.-China Sorghum Trade Analysis Within the Trade Conflict: Growth, Trends, and Forecast
}

\author{
Wei Zhang \\ University of Kentucky \\ Mary A. Marchant \\ Virginia Tech
}

This research was conducted in 2017, prior to the U.S.-China trade dispute, and anticipated the potential risk for U.S. sorghum exports if China, the U.S. top market for sorghum, imposed trade restrictions. The USDA-ERS China model was used to analyze the impacts on U.S. and global sorghum trade. Results show that the decrease of China's sorghum imports resulted in less sorghum demand and a lower sorghum price in the global market. Sorghum exports for U.S. and other major sorghum exporters decreased significantly. The results show the necessity for U.S. sorghum exporters to seek new sorghum export opportunities worldwide. Meanwhile, U.S. sorghum exporters may change their cropping patterns to continue making profits by switching out of sorghum.

Keywords: China, U.S.-China Trade, Sorghum, USDA-ERS China Model, Simulation, Global Impacts, Agricultural Policy

\section{INTRODUCTION}

This research conducted in 2017 as a Masters' thesis (Zhang, 2017), anticipated the potential reduction of U.S.-China trade for sorghum. Since then multiple events have transpired throughout the escalating U.S.-China trade war (Marchant and Wang, 2018) including (1) China's anti-dumping and countervailing duty investigation against U.S. sorghum imports initiated on February 4, 2018; (2) China's imposition of a 178.6\% tariff on U.S. sorghum imports on April 18, 2018 (Hansen, et al., 2018). Both were short-lived and have since been withdrawn on May 18, 2018; however a 25 percent retaliatory tariff imposed in July 2018 remains in place as of May 8, 2019. On a more positive note, China made its largest purchase of U.S. sorghum in March 2019 since tariffs were imposed (Polansek, 2019).

Regardless of the ongoing trade conflict, China is the world's largest agricultural producing country and a strong force in international trade. China is currently the world's dominant sorghum importer, and its sorghum demand is a major reason why global sorghum trade is expected to gradually increase over the next decade (Tran et al., 2015). Despite the increasing volume of imports, there is a possibility that sorghum imports will decline significantly because of the change of China's corn policy, specifically changes in China's support price and temporary reserve programs. Chinese importers started to decrease their rate of sorghum imports from the U.S. beginning in 2016 as China ended these programs; thus lowering its corn price and reducing the demand for substitute feed. According to the prediction from the 
Food and Agriculture Organization of the United Nations, a 50\% reduction of China's sorghum imports will result from Chinese corn policy change (FAO, 2014).

In the past few decades, the rapid growth of China's economy led to a significant change in consumption patterns. The demand for dairy and meat products increased dramatically, which promoted China's livestock industry. Simultaneously, with high urbanization rates, the Chinese economy structure is transforming from a producer-driven economy to a consumer-driven economy (Sagami, 2011). Accordingly, the food consumption structure is shifting from grains to meat; thus, China's high meat demand is promoting a fast-developing feed industry (Gale, 2015). Sorghum demand is a derived demand from the demand for food and feed, and the primary demand is for feed. The growing demand for livestock, in turn, resulted in a growing demand for feed grains, such as corn and sorghum.

The objective of this research seeks to analyze the impacts on U.S. and global sorghum trade if China restricts sorghum imports. To answer this question, this research will use the U.S. Department of Agriculture-Economic Research Service (USDA-ERS) China Model and the Country-Commodity Linked System (USDA-OCE \& WAOB, 2017) to simulate the impacts of U.S. sorghum exports and the reduction of sorghum's global price, global production, and global trade volumes. The simulation will be based on three scenarios, each decrease China's sorghum imports. The three scenarios are (1) if China's sorghum import volume decreased by 50\% from USDA-ERS's baseline projection; (2) if China's sorghum import volume decreased by $35 \%$ each year from the previous year; and (3) if China's sorghum import volume decreased by $70 \%$ from USDA-ERS's baseline projection in year one and by $90 \%$ from the USDA-ERS's baseline projection in subsequent years.

China's agricultural and trade policies in the corn sector are driving much of the growth for sorghum demand and imports. Corn is the primary feed grain in China. China initiated a price support program and a temporary reserve program for corn in 2008 to support Chinese farmers' incomes and to move China toward self-sufficiency (Gale, 2013). Under these programs, once the corn market price is less than the support price, the Chinese authorities purchase corn from farmers at the support price, and accumulate corn in national storage facilities (Wu and Zhang, 2016). Under this price support policy, China's support price for corn continuously increased over time, which increased China's domestic corn production and generated huge corn stockpiles (Hejazi and Marchant, 2017).

Since China imposes tariff rate quota (TRQs) on corn imports, China's corn price remained high domestically and imports of cheaper feed substitutes increased, noting there were no restrictions on sorghum imports. In this regard, sorghum is considered as a low-cost feed substitute for corn, and China was projected to maintain high sorghum import volumes (Hansen and Gale, 2014). As an example showing the increase in China's feed versus food use, China's sorghum feed-to-use ratio increased significantly from less than 10\% in 2010 to more than 80\% in 2014. In contrast, China's corn feed-to-use ratio remained steady during this period at approximately $70 \%$ (Wang and Malaga, 2016). However, the magnitude of China's sorghum market demand is still very small compared with China's corn market, and China's corn demand is much larger than China's sorghum demand.

From 2016 onward, the situation began to change in China based on three reasons: a huge amount of corn stockpiles; cheaper but limited corn imports from the world market; and quality deterioration of corn stocks. China ended its price support policy and temporary reserve program for corn in two geographic areas, three northeastern provinces--Heilongjiang, Jilin, Liaoning--and Inner Mongolia, as a pilot program to decrease China's excessive corn stockpiles. On March 28, 2016, Liu Xiaonan, China's Deputy Director of the Economy and Trade Department of the National Development and Reform Commission (NDRC), announced that the temporary reserve policy in the three northeastern provinces and Inner Mongolia would be terminated. Instead, a new mechanism of "marketized purchases" and a direct payment subsidy policy toward corn would be implemented in these areas (China Politics, 2016). The change of China's corn policy resulted in a lower Chinese domestic corn price, which brought higher corn demand. Thus, the demand for sorghum, which is one of most important corn substitutes for feed use, decreased significantly. This new policy decreased China's corn production and corn price; imports of sorghum decreased as well. 
Thus, prior the current trade war, U.S.-China sorghum trade was a temporary success story and it provides an example of U.S. market expansion in foreign countries. This research analyzes the impact of a decrease in sorghum imports in year 2016 forward; thus after the corn policy change. This study is important because it presents an understanding of China's sorghum trade policies and knowledge for U.S. sorghum exporters to evaluate potential opportunities and risks in U.S.-China sorghum trade. This research could also be used as a reference for sorghum exporting countries (the U.S., Australia, Argentina) to prepare for changes in Chinese sorghum policies.

\section{BACKGROUND}

Sorghum is a significant feed crop used throughout the world, which is drought tolerant and provides high-energy as a major animal feed (Tan et al., 2015). As important feed grains, sorghum and corn are used interchangeably to feed animals due to their similar production costs and nutritional content; therefore, farmers choose which to grow based on their local growing environment and market conditions. Compared to corn, sorghum is grown in drier areas because of its drought resistance characteristic (Tan et al., 2015). China traditionally imports sorghum from Australia to produce rice wine, which is called baijiu. Chinese domestic sorghum mainly goes to food and the baijiu industry. Up until recent years, because of corn's tariff-rate quota (TRQ) and the controversy over genetically modified organisms (GMOs) in China, sorghum became an animal feed substitute for corn (Liu \& Zhou, 2016). Thus, China's imports of sorghum increased significantly; and accordingly, the global sorghum price increased as well. From the global sorghum trade perspective, China, Mexico and Japan are major sorghum importers; and from 2013/14 through 2017/18 marketing years (MY) China ranks first among all sorghum importers in the world (USDA-FAS, 2014a\&b, 2017).

\section{FIGURE 1 \\ SORGHUM IMPORTS FOR SELECTED COUNTRIES (CHINA, MEXICO, JAPAN)}

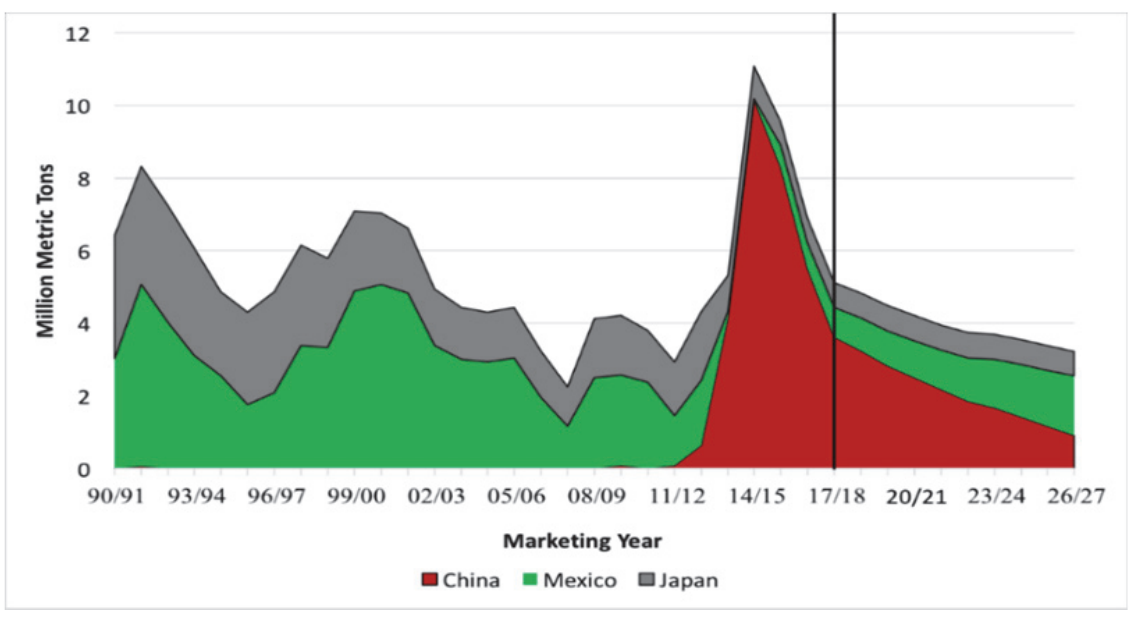

Source: USDA-Foreign Agriculture Service (FAS), Production, Supply and Distribution (PS\&D), 2017.

USDA-OCE-WAOB, USDA Agricultural Projections to 2026, Long-term Projections Report OCE-2017-1, February 2017.

(Note: Data prior to 2016 are actual data and data after 2016 are USDA baseline projections.)

Figure 1 shows sorghum imports for selected major sorghum importers. Data before MY 2016/17 is actual data, and data after MY 2016/17 is USDA-ERS's baseline projection. Figure 1 shows that Chinese sorghum imports increased dramatically since MY 2012/13, and it increased up to a historical peak in MY 
2014/15. To expand on this growth, in 2012/13, Chinese sorghum imports reached 1.08 million metric tons (MMT), increased 114\% compared to the import volume in 2011/12. In 2013/14, sorghum imports continued to increase, reached 5.78 MMT and increased by $435 \%$ compared to the previous year, and growth continued in 2014/15 (USDA, 2015). As mentioned earlier, because of the change of China's sorghum imports in 2016, Chinese sorghum planting areas started to increase in 2016. China's sorghum planting area reached 120.76 million acres in 2016, an increase by $8.51 \%$ compared to 2015 (Ministry of Agriculture of the People's Republic of China, 2017).

Traditionally, sorghum ranks as the third largest cereal grain in the U.S., and it is grown throughout the central region on drylands. In 2015, U.S. sorghum planting areas reached 8.5 million acres, and 597 million bushels were harvested (USDA-NASS, 2016). From a global perspective, the U.S. is the largest sorghum feed producer and exporter in the global sorghum market. In MY 2012/13, the U.S. accounts for $70 \%$ of total global sorghum exports (Tran et al., 2015). In addition, U.S. sorghum has a lower price and a lower tannin content, which is more suitable for feed use compared to other countries, such as Australia and Argentina.

\section{FIGURE 2}

\section{U.S. SORGHUM EXPORTS AND CHINESE IMPORTS, MY 2000/01-2016/17}

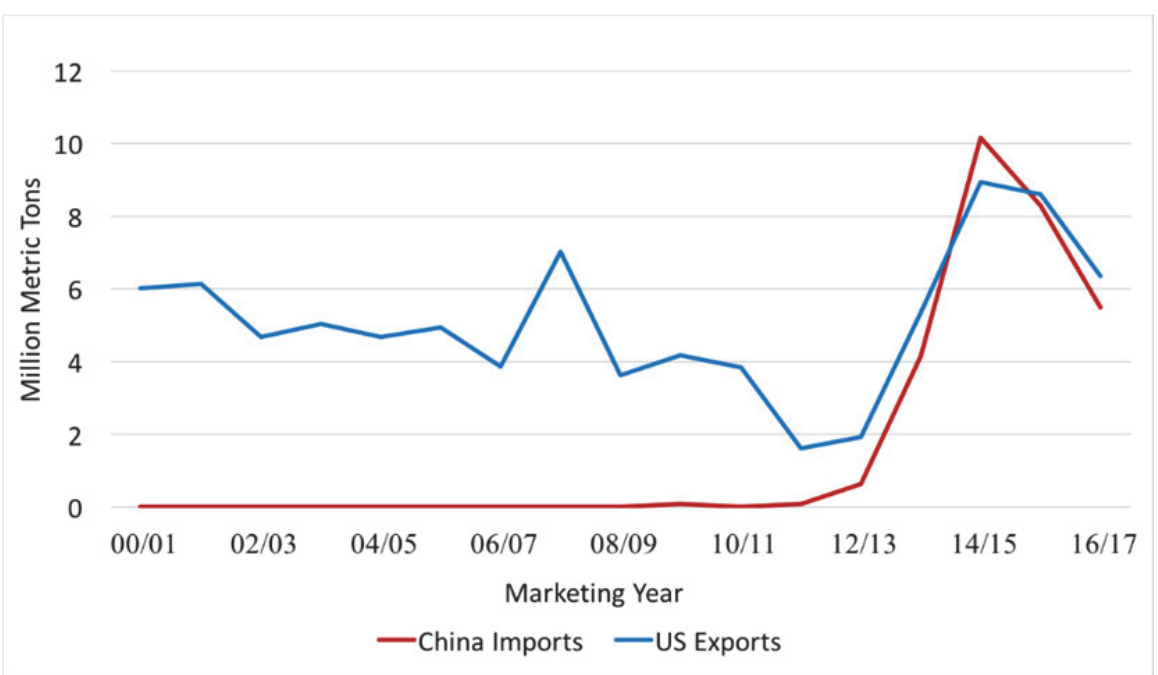

Source: USDA-Foreign Agriculture Service (FAS), Production, Supply and Distribution (PS\&D), 2017.

Since 2013, U.S. sorghum has been widely accepted by China's feed industry. China's corn policy change was a great opportunity for U.S. sorghum exporters to open up China's sorghum market. The U.S. seized this opportunity to gain access to the Chinese sorghum market. China's sorghum imports from the U.S. have risen tremendously, making China the most important destination for U.S. sorghum exports since 2013. As shown in Figure 2, from MY 2012/13 to MY 2014/15, China's sorghum imports increased from almost zero to approximately $10 \mathrm{MMT}$, while the U.S. sorghum exports increased by approximately $350 \%$ during the same time period, from 2 MMT to 9 MMT (USDA-FAS-PS\&D, 2017).

\section{MODELING}

\section{Methods and Procedure}

This research builds upon prior studies by Hansen et al. (2011 \& 2015) as well as Wang and Malaga (2015) and uses the 2017 USDA baseline projections for analysis. The modeling system used in this research contains both the USDA-ERS China model and the Country-Commodity Linked System (CCLS; 
USDA-OCE \& WAOB, 2017). This USDA-ERS China model and the CCLS refer to the mathematical solution of a simultaneous set of differential equations (Pindyck and Rubinfeld, 1981). The USDA-ERS China model is a large scale multi-country and multi-commodity partial equilibrium dynamic simulation model, and this model was developed for conducting policies scenarios at national and regional levels. The CCLS combines 42 country or regional models, and determines equilibrium prices and trade, to simultaneously clear 24 agricultural commodity markets and enable scenario projections by year, for 10 years into the future. The system as a whole contains about 15,000 equations. The CCLS includes supply, demand, prices, and policies; and the CCLS is used for analyzing the impacts toward U.S. and international agricultural markets and trade driven by potential policy changes. Both the USDA-ERS China model and the CCLS use data from the USDA-FAS-PS\&D, China's National Bureau of Statistics, and Chinese government agencies (see the appendix for more information on the model).

In an open economy, a China sorghum trade flows can be expressed as

$$
\begin{aligned}
& E D_{C H}^{S G}=D_{C H}^{S G}-S_{C H}^{S G}+\Delta S T K_{C H}^{S G} \\
& E S_{W}^{S G}=S_{W}^{S G}-D_{W}^{S G}+\Delta S T K_{W}^{S G} \\
& E D_{C H}^{S G}=E S_{W}^{S G}
\end{aligned}
$$

where

$$
\begin{aligned}
& E D_{C H}^{S G}=\text { China's excess sorghum demand } \\
& D_{C H}^{S G}=\text { China's domestic sorghum demand } \\
& S_{C H}^{S G}=\text { China's domestic sorghum supply } \\
& \Delta S T K_{C H}^{S G}=\text { China's sorghum stock change } \\
& E S_{W}^{S G}=\text { World excess sorghum supply, excluding China } \\
& S_{W}^{S G}=\text { World sorghum supply, excluding China } \\
& D_{W}^{S G}=\text { World sorghum demand, excluding China } \\
& \Delta S T K_{W}^{S G}=\text { World's sorghum stock change excluding China. }
\end{aligned}
$$

Equation (1) is China's excess sorghum demand, equation (2) is world excess sorghum supply excluding China, equation (3) is the market clearing equation in this simplified China sorghum trade model.

To examine the impacts of China's policies on the market access of U.S. sorghum exports to China, a more detailed excess demand equation is represented for sorghum below

$$
E D_{C H}^{S G}=D_{C H}^{S G}\left(P_{C H}^{S G}, A, \alpha\right)-S_{C H}^{S G}\left(P_{C H}^{S G}, B, \beta\right)-\Sigma I M P_{C H}^{S G}+\Delta S T K_{C H}^{S G}
$$

where previous definitions hold and

$P_{C H}^{S G}=$ China's domestic sorghum price

$A=$ The vector of demand shifters (population, income, price of substitutes and complements, etc.)

$\alpha=$ China's sorghum policies (demographic factors, government policies and regulations)

$B=$ The vector of supply shifters (input costs, price of substitutes, technological progress and number of producers, etc.)

$\beta=$ The policy instruments that affect production decisions (farm size, yield, cost of production, etc.)

$\Sigma I M P_{C H}^{S G}=$ The sum of China's imports from other countries (excluding the U.S.) 


\section{Demand}

As discussed above, sorghum demand is a derived demand from the demand for food and feed, and the primary demand is for feed. Total demand equals the sum of food demand and feed demand. Thus, China's domestic demand for sorghum can be expressed as

$D_{C H}^{S G}=D^{\text {Food }}+D^{\text {Feed }}$

where previous definitions hold and

$D^{\text {Food }}=$ China's domestic food demand for sorghum

$D^{\text {Feed }}=$ The domestic feed demand for sorghum

Food demand is modeled by population and per capita consumption for both rural and urban areas, which is a function of its own consumer price, substitute food prices, and income. Feed demand is a function of derived feed demand, based on the quantity of pork and poultry produced in commercial and specialized livestock sectors (Hansen et al., 2017).

From equation (5), each of the variables in the above equation of China's domestic demand for sorghum are defined below $-D_{t}^{\text {Food }}$ and $D_{t}^{\text {Feed }}$. The food demand equation can be expressed as the sum of urban food demand $\left(D_{t}^{p c u} \cdot P O P^{u}\right)$ and rural food demand $\left(D_{t}^{p c r} \cdot P O P^{r}\right)$. Urban food demand equals per capita food demand in China's urban areas $\left(D_{t}^{p c u}\right)$ multiplied by China's population in urban areas $\left(P O P^{u}\right)$. Rural food demand equals per capita food demand in China's rural areas $\left(D_{t}^{p c r}\right)$ multiplied by China's population in rural areas $\left(P O P^{r}\right)$

$D_{t}^{\text {Food }}=D_{t}^{p c u} \cdot P O P^{u}+D_{t}^{p c r} \cdot P O P^{r}$

where previous definitions hold and

$D_{t}^{p c u}=$ Per capita food demand for sorghum in China's urban areas at time $\mathrm{t}$

$P O P^{u}=$ China's population in urban area at time $\mathrm{t}$

$D_{t}^{p c r}=$ Per capita food demand for sorghum in China's rural areas at time $\mathrm{t}$

$P O P^{r}=$ China's Population in rural areas at time $\mathrm{t}$

From equation (6), per capita food demand for sorghum at time $t$ in urban and rural areas are defined as $D_{t}^{p c u}$ and $D_{t}^{p c r}$ respectively. Equation (7) defines per capita food demand in urban areas.

$D_{t}^{p c u}=D_{t-1}^{p c u} \times\left(1+\% \Delta P_{S G U} \cdot \varepsilon_{S G U}^{S G}+\% \Delta P_{E g g u} \cdot \varepsilon_{E g g u}^{S G}+\% \Delta P_{\text {Poultryu }} \cdot \varepsilon_{\text {Poultryu }}^{S G}+\% \Delta P_{\text {Porku }} \cdot \varepsilon_{\text {Porku }}^{S G}+\right.$

$\% \Delta P\left(\right.$ Beef \& Veal) $u \cdot \varepsilon_{(\text {Beaf and Veal })}^{S G}+\% \Delta P_{\text {Otheru }} \cdot \varepsilon_{\text {Otheru }}^{S G}+\% \Delta$ Per capita GDP urban $\left.\cdot \varepsilon_{P C}^{S G}\right)$

where previous definitions hold and

$\% \Delta P_{S G U}=$ Percentage change of sorghum price in urban areas

$\varepsilon_{S G U}^{S G}=$ Own-price elasticity for sorghum food demand in urban areas

$\% \Delta P_{E g g u}=$ Percentage change of egg price in urban areas

$\mathcal{E}_{E g g u}^{S G}=$ Cross-price elasticity between egg and sorghum food demand in urban areas

$\% \Delta P_{\text {Poultryu }}=$ Percentage change of poultry price in urban areas

$\varepsilon_{\text {Poultryu }}^{S G}=$ Cross-price elasticity between poultry and sorghum food demand in urban areas

$\% \Delta P_{\text {Porku }}=$ Percentage change of pork price in urban areas

$\varepsilon_{\text {Porku }}^{S G}=$ Cross-price elasticity between pork and sorghum food demand in urban areas

$\% \Delta P_{(B e e f \& \text { Veal })}=$ Percentage change of beef \& veal price in urban areas

$\mathcal{E}_{(\text {Beaf and Veal })} u=$ Cross-price elasticity between beef \& veal and sorghum food demand in urban areas 
$\% \Delta P_{\text {Otheru }}=$ Percentage change of other commodities' price in urban areas

$\varepsilon_{\text {Otheru }}^{S G}=$ Cross-price elasticity between other commodities and sorghum food demand in urban areas

$\% \triangle P$ er capita GDP urban $=$ Percentage change of per capita GDP in urban areas

$\varepsilon_{P C}^{S G}=$ Income elasticity of sorghum food demand in urban areas

Per capita urban food demand $\left(D_{t}^{p c u}\right)$ can be expressed as China's per capita urban food demand for sorghum in the previous year $\left(D_{t-1}^{p c u}\right)$, plus $D_{t-1}^{p c u}$ multiplied by the percentage change of food consumption for certain commodities in urban areas: sorghum, egg, poultry, pork, beef and veal, etc. The percentage change of food demand in urban areas $(\% \Delta Q)$ equals the price elasticity $\left(\varepsilon=\frac{\% \Delta Q}{\% \Delta P}\right)$ multiplied by the percentage change of price $(\% \Delta P)$ for each of the above commodities, which can be expressed as $\% \Delta P$. $\varepsilon$. This method of multiplying the elasticity and the percent change of price is used extensively in this simulation model to obtain percentage change of quantity. For sorghum, we use the own-price elasticity. For other commodities, we use cross-price elasticities (e.g., $\% \Delta Q^{S G} / \% \Delta P^{P o r k}$ ).

A similar method is used to obtain per capita food demand in rural areas $\left(D_{t}^{p c r}\right)$. However, in rural areas, commodities are limited to sorghum and pork. Equation (8) is similar to equation (7) by changing the percentage change of food demand to reflect this restriction in rural areas

$D_{t}^{p c r}=D_{t-1}^{p c r} \times\left(1+\% \Delta P_{S G R} \cdot \varepsilon_{S G R}^{S G}+\% \Delta P_{P o r k r} \cdot \varepsilon_{P o r k r}^{S G}+\% \Delta P_{\text {Otherr }} \cdot \varepsilon_{\text {Otherr }}^{S G}+\% \Delta\right.$ Per capita GDP rural .
$\left.\varepsilon_{P C}\right)$

where previous definitions hold and

$\% \triangle P_{S G R}=$ Percentage change of sorghum price in rural areas

$\varepsilon_{S G R}^{S G}=$ Own-price elasticity for sorghum food demand in rural areas

$\% \Delta P_{\text {Porkr }}=$ Percentage change of pork price in rural areas

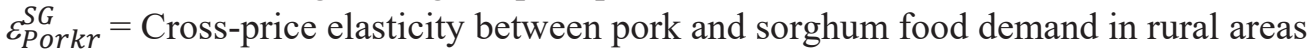

$\% \Delta P_{\text {Otherr }}=$ Percentage change of other commodities' price in rural areas

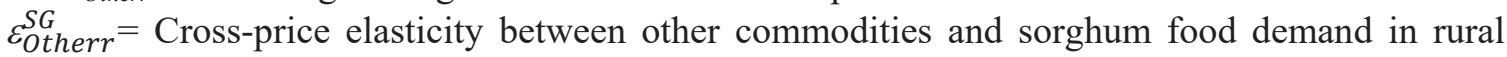
areas

$\% \triangle P$ er capita GDP rural $=$ Percentage change of per capita GDP in rural areas

$\varepsilon_{P C}^{S G}=$ Income elasticity of sorghum food demand in rural areas

Now we turn to feed demand as shown in equation (9). From equation (5), China's domestic feed demand of sorghum at time $\mathrm{t}$ is defined as $D_{t}^{\text {Feed }}$, which also can be expressed as China's domestic feed demand of sorghum in the previous year $\left(D_{t-1}^{\text {Feed }}\right)$, plus the $D_{t-1}^{\text {Feed }}$ multiplied by the sum of the percentage change of sorghum feed demand of certain commodities: sorghum and corn. The percentage change of sorghum feed demand for both sorghum and corn equals the respective price elasticities for sorghum and corn multiplied by their corresponding percentage change of price

$D_{t}^{F e e d}=D_{t-1}^{F e e d} \times\left(1+\% \Delta P_{S G} \cdot \varepsilon_{S G}^{S G}+\% \Delta P_{C o r n} \cdot \varepsilon_{C o r n}^{S G}+\% \Delta G F R \cdot \underset{\varepsilon_{G F R}^{S G}}{S G}\right)$

where previous definitions hold and

$D_{t}^{\text {Feed }}=$ China's domestic feed demand of sorghum at time $\mathrm{t}$

$D_{t-1}^{F e e d}=$ China's domestic feed demand of sorghum at time t-1

$\% \Delta P_{S G}=$ Percentage change of domestic sorghum price

$\varepsilon_{S G}^{S G}=$ Own-price elasticity for sorghum feed demand

$\% \Delta P_{\text {Corn }}=$ Percentage change of domestic corn price

$\varepsilon_{C o r n}^{S G}=$ Cross-price elasticity between corn and sorghum feed demand 
$\% \triangle G F R=$ Percentage change of grain feeding requirement

${ }_{E_{G F R}^{S G}}^{S G}$ Elasticity of sorghum feed demand with respect to a change in the grain feeding requirement

\section{Supply}

China's domestic supply for sorghum $\left(S_{C H}^{S G}\right)$ in equation (10) equals China's domestic harvested area $\left(H A_{t}^{S G}\right)$ multiplied by China's domestic sorghum yield $\left(Y_{C H}^{S G}\right)$, which can be expressed as

$S_{C H}^{S G}=H A_{C H}^{S G} \cdot Y_{C H}^{S G}$

$S_{C H}^{S G}=$ China's domestic supply of sorghum

$H A_{C H}^{S G}=$ China's domestic sorghum harvested area

$Y_{C H}^{S G}=$ China's domestic sorghum yield

The variables in equation (10) are further specified in equations (11) and (12). Equation (11) specifies China's domestic sorghum harvested area at time $\mathrm{t}$ :

$H A_{t}^{S G}=H A_{t-1}^{S G} \times\left(1+\% \Delta\right.$ Sorghum Expected Return $\cdot \varepsilon_{S E R}+\% \Delta$ Corn Expected Return $\cdot \varepsilon_{C E R}^{S G}+$ $\% \Delta$ Soybeans Expected Return $\left.\cdot \varepsilon_{S o y E R}^{S G}\right)$

where previous definitions hold and

$\% \Delta$ Sorghum expected return $=$ Percentage change of sorghum expected returns

$\varepsilon_{S E R}=$ Elasticity of sorghum harvested areas with respect to a change in the sorghum expected return

$\% \Delta C$ Corn expected return $=$ Percentage change of corn expected returns

$\varepsilon_{C E R}^{S G}=$ Elasticity of sorghum harvested areas with respect to a change in the corn expected return

$\% \Delta$ Soybean expected return $=$ Percentage change of soybean expected return

${ }_{S O y E R}^{S G}=$ Elasticity of sorghum harvested areas with respect to a change in the soybean expected return

Harvested area in year ' $\mathrm{t}$ ' $\left(H A_{t}^{S G}\right)$ can be expressed as China's domestic sorghum harvested areas in the previous year $\left(H A_{t-1}^{S G}\right)$, plus the sum of $H A_{t-1}^{S G}$ multiplied by the percentage change of sorghum harvested areas from certain commodities: sorghum, corn and soybeans. This is because Chinese farmers can choose growing commodities with higher expected returns. The percentage change of harvested areas for these commodities equals their corresponding expected return elasticities of sorghum harvested areas multiplied by the percentage change of their expected returns accordingly.

Equation (12) specifies China's domestic sorghum yields, $Y_{C H}^{S G}$, which can be expressed as China's domestic sorghum yields in the previous year $\left(Y_{t-1}^{S G}\right)$, plus $Y_{t-1}^{S G}$ multiplied by the percentage change of a three-year sorghum yield moving average.

$Y_{t}^{S G}=Y_{t-1}^{S G} \times\left(1+\% \Delta M A_{S R}\right)$

where previous definitions hold and

$\% \Delta M A_{S R}=$ percentage change of three-year sorghum yields' moving average 


\section{Imports}

Equation (13) specifies China's sorghum imports from the global market at time t $\left(I M P_{t}^{S G}\right)$ :

$$
I M P_{t}^{S G}=I M P_{t-1}^{S G} \times\left(1+\% \Delta I P \cdot \varepsilon_{I P}^{S G}+\% \Delta D_{\text {Feed }} \cdot \varepsilon_{F e e d}^{S G}\right)
$$

$I M P_{t}^{S G}=$ China's sorghum imports from the global sorghum market at time $\mathrm{t}$

$I M P_{t-1}^{S G}=$ China's sorghum imports from the global sorghum market at time t-1

$\% \Delta I P=$ Percentage change of China's sorghum import price

$\varepsilon_{I P}^{S G}=$ Price elasticity of China's sorghum imports

$\% \Delta D_{\text {Feed }}=$ Percentage change of China's feed demand

$\underset{\varepsilon_{\text {Feed }}^{S G}}{S G}=$ Elasticity of China's sorghum imports with respect to a change in the China's feed demand

China's global sorghum imports in year ' $\mathrm{t}$ ' $\left(I M P_{t}^{S G}\right)$ equals the sum of China's sorghum imports from the global market in the previous year $\left(I M P_{t-1}^{S G}\right), I M P_{t-1}^{S G}$ multiplied by the percentage change of sorghum imports stemming from the import price change $(\% \Delta I P)$ multiplied by its elasticity $\left(\varepsilon_{I P}\right)$. Similarly, the last term is $I M P_{t-1}^{S G}$ multiplied by the percentage change of sorghum imports stemming from the change of China's feed demand $\left(\% \Delta D_{F e e d}\right)$ multiplied by its elasticity $\left(\varepsilon_{F e e d}\right)$.

\section{Stock Change}

Equation (14) specifies China's domestic sorghum stock change $\left(S T K_{t}^{S G}\right)$, which equals China's domestic sorghum stock in the previous year $\left(S T K_{t-1}^{S G}\right)$, plus the product of $S T K_{t-1}^{S G}$ multiplied by the percentage change of sorghum stocks. The percentage change of sorghum stocks equals the price elasticity of sorghum stocks $\left(\varepsilon_{F M P}\right)$ multiplied by the percentage change of sorghum price $\left(\% \Delta P_{F M P}\right)$

$S T K_{t}^{S G}=S T K_{t-1}^{S G} \times\left(1+\% \Delta P_{F M P} \varepsilon{ }_{F M P}^{S G}\right)$

where

$S T K_{t}^{S G}=$ China's domestic sorghum stock change at time t

$S T K_{t-1}^{S G}=$ China's domestic sorghum stock change at time t-1

$\% \Delta P_{F M P}=$ Percentage change of sorghum price

$\varepsilon_{F M P}^{S G}=$ Price elasticity of sorghum stocks

\section{EMPIRICAL RESULTS}

\section{Baseline Description}

As a reminder, this research is conducted using USDA's 2017 baseline projections. Although the 2018/19 trade war had yet to begin and was not foreseen by the authors, this research did anticipate restrictions on U.S. sorghum exports to China. Table 1 describes the sorghum output baseline projection. 
TABLE 1

SORGHUM OUTPUT BASELINE FOR THE THREE SCENARIOS

\begin{tabular}{llllllllll}
\hline \multicolumn{8}{c}{ SORGHUM OUTPUT BASE } \\
\hline $\begin{array}{l}\text { Crop } \\
\text { year }\end{array}$ & $\begin{array}{l}\text { Area } \\
\text { harvest }\end{array}$ & Yield & Production & Imports & Exports & $\begin{array}{l}\text { Total } \\
\text { cons }\end{array}$ & $\begin{array}{l}\text { Ending } \\
\text { stocks }\end{array}$ & $\begin{array}{l}\text { Feed } \\
\text { use }\end{array}$ & $\begin{array}{l}\text { Food } \\
\text { use }\end{array}$ \\
$16 / 17$ & 650 & 4.923 & 3200 & 5500 & 10 & 9300 & 357 & 7200 & 2100 \\
$17 / 18$ & 666 & 4.945 & 3294 & 3630 & 8 & 6920 & 353 & 4852 & 2068 \\
$18 / 19$ & 675 & 4.972 & 3354 & 3240 & 7 & 6554 & 387 & 4473 & 2080 \\
$19 / 20$ & 681 & 4.982 & 3394 & 2829 & 6 & 6194 & 409 & 4089 & 2105 \\
$20 / 21$ & 688 & 4.988 & 3433 & 2509 & 5 & 5924 & 422 & 3795 & 2128 \\
$21 / 22$ & 695 & 4.986 & 3466 & 2172 & 5 & 5642 & 413 & 3493 & 2149 \\
$22 / 23$ & 704 & 4.991 & 3513 & 1850 & 5 & 5366 & 406 & 3203 & 2163 \\
$23 / 24$ & 710 & 4.985 & 3541 & 1670 & 4 & 5197 & 415 & 2997 & 2200 \\
$24 / 25$ & 718 & 4.983 & 3577 & 1421 & 4 & 4982 & 427 & 2770 & 2212 \\
$25 / 26$ & 721 & 4.994 & 3600 & 1157 & 4 & 4788 & 392 & 2561 & 2227 \\
$26 / 27$ & 725 & 4.997 & 3624 & 913 & 4 & 4569 & 356 & 2335 & 2234 \\
\hline
\end{tabular}

Source: USDA-Foreign Agriculture Service (FAS), Production, Supply and Distribution (PS\&D), 2017.

USDA-OCE-WAOB, USDA Agricultural Projections to 2026, Long-term Projections Report OCE-2017-1, February 2017.

Note: Area harvest is in thousand hectares (HA); yield is in metric ton per hectare; all other variables are in thousand metric tons. Cons equals consumption.

Prior to any policy scenarios, figure 3 describes the USDA-ERS's baseline projection focusing on China's domestic sorghum market, including China's sorghum demand (both food demand and feed demand) and imports. Data before MY 2016/17 is actual data, and data after MY 2016/17 is USDAERS's baseline projection. Figure 3 shows the significant increase of China's sorghum food demand, feed demand, and imports from MY 2012/13 to MY 2014/15. It shows that since MY 2000/01, China's sorghum food demand has been steady. This also indicates that the increase of China's sorghum imports is from the increase of China's feed demand. China's sorghum feed demand was almost zero before MY 2012/13, but it reached 11 MMT in MY 2014/15 (USDA-FAS-PS\&D, 2017). Figure 3 also shows the actual data and projections of China's sorghum imports. It shows that China rarely imported sorghum from the global market before MY 2012/13; however, imports increased to 10 MMT in MY 2014/15 (USDA-FAS-PS\&D, 2017). Figure 3 also indicates that both China's sorghum demand and imports started to decline in MY 2015/16. 


\section{FIGURE 3 \\ CHINA'S DOMESTIC SORGHUM DEMAND AND IMPORTS (MILLION METRIC TONS)}

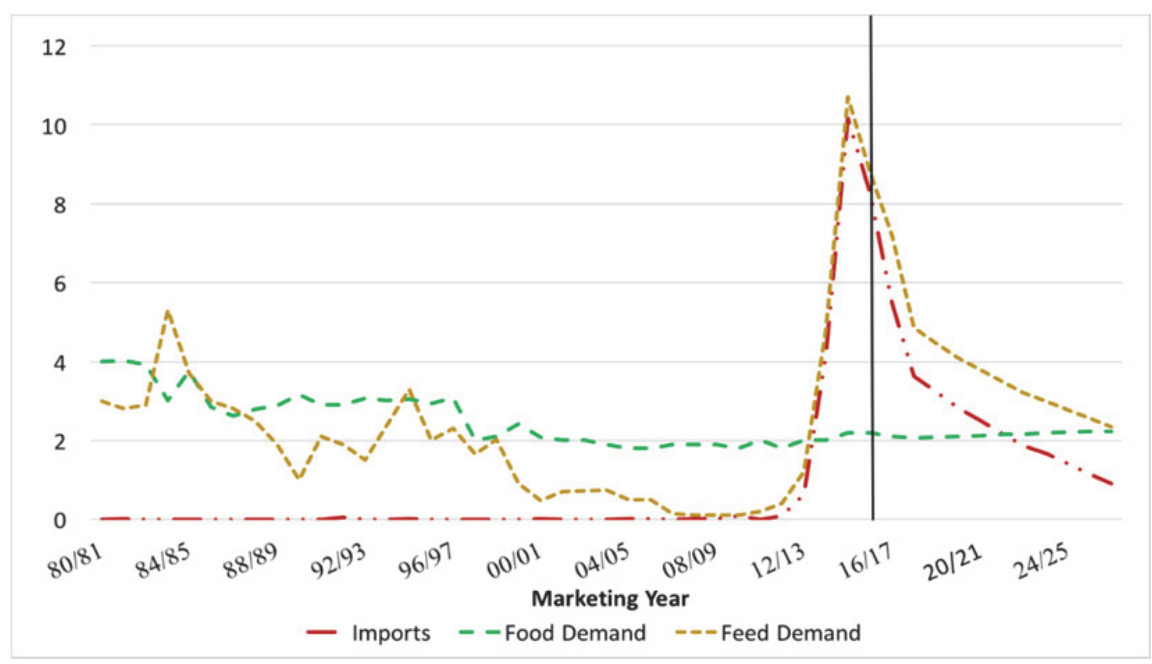

Source: USDA-Foreign Agriculture Service (FAS), Production, Supply and Distribution (PS\&D), 2017.

USDA-OCE-WAOB, USDA Agricultural Projections to 2026, Long-term Projections Report OCE-2017-1, February 2017.

(Note: Data prior to 2016 are actual data and data after 2016 are USDA baseline projections.)

The decline of both China's sorghum imports and China's sorghum demand stems from China's decreased corn price in MY 2015/16. In early 2016, China ended its price support policy and temporary reserve programs for corn in two areas, Northeastern provinces and Inner Mongolia, as a pilot program to decrease China's excessive corn stockpiles. This new corn policy reduced China's corn price, and China's feed companies decreased substituting low-priced sorghum for high-priced corn. Thus, China's sorghum imports and demand decreased as a result of the implementation of this new corn policy. According to USDA-ERS's baseline projection, this declining trend will continue, and China's sorghum imports will decline from 5.5 MMT in MY 2016/17 to 0.9 MMT in MY 2026/27.

\section{China Sorghum Import Reduction Scenarios}

All the variables involved in the USDA-ERS China model and the CCLS above will be affected if we shock China's sorghum imports (Equation 13) for different scenarios. Recall that prior to the trade war China had no restrictions on sorghum imports; also recall the three scenarios described above: (1) if China's sorghum import volume decreased by 50\% from USDA-ERS's baseline projection; (2) if China's sorghum import volume decreased by $35 \%$ each year from the previous year; and (3) if China's sorghum import volume decreased by $70 \%$ from USDA-ERS's baseline projection in year one and by $90 \%$ from the USDA-ERS's baseline projection in subsequent years. The scenarios of this research were set up based on China's probable sorghum import shock stemming from changes in China's corn policy. Finding the impacts of these scenarios for the U.S. and the global marketplace helps to project the trend of sorghum global trade in terms of price and volume.

The import decline shock occurs in MY 2017/18 and continues throughout the simulation period through 2026/27. Listed below are results of the three scenarios from different perspectives. First, we examine the impacts of the decline in China's sorghum imports on China's domestic sorghum market. Next, we look at the impacts on the U.S. and global sorghum markets. Given that sorghum and corn are feed substitutes, we then present impacts on China's domestic corn market. And finally, given that 
sorghum is a derived demand, we examine the impacts on China's pork and poultry markets. Results are also presented by comparing the three scenarios.

\section{Results by Perspective}

China's Domestic Sorghum Market Impacts

In response to the decline in sorghum imports, all three scenarios resulted in an increase in the price of sorghum in China, a decrease in domestic consumption, and an increase in Chinese sorghum planting area as expected. For scenario one, the domestic sorghum price increased by $27.41 \%$ for the first year after the shock, which occurred on MY 2017/18, and increased by $22.02 \%, 14.21 \%$ and $14.55 \%$ for the following three years, respectively. Accordingly, China's domestic sorghum consumption decreased by $21.51 \%, 20.73 \%, 18.07 \%$ for the first three years after the shock, respectively. Sorghum planting areas and yields increased slightly, by $2.36 \%$ and $1.36 \%$ respectively for the first year after the shock. For scenario two , the domestic sorghum price increased by $14.9 \%, 25.23 \%$, and $30.8 \%$ for the first three years after the shock, respectively. Accordingly, China's domestic sorghum consumption decreased by $11.69 \%$ for the first year, $18.6 \%$ for the second year, and $21.98 \%$ for the third year after the shock. The planting areas and yields increased by $1.28 \%$ and $1.25 \%$ respectively for the first year, and increased by $3.12 \%$ and $2.12 \%$ for the second year. Thus, this shows an expanding sorghum planting area in China. For scenario three, the domestic sorghum price increased by $38.37 \%, 51.44 \%$, and $27.73 \%$ for the first three years after the shock, respectively. Accordingly, domestic consumption decreased by $30.12 \%$ for the first year, $37.06 \%$ for the second year and $32.38 \%$ for the third year after the shock. The planting areas and yields increased by $3.3 \%$ and $2.73 \%$ respectively for the first year, and increased by $6.86 \%$ and $3.52 \%$ for the second year, showing an expanding planting area for sorghum in China.

\section{The U.S. and Global Sorghum Markets Impacts}

For scenario one, as expected, the model simulation results show a decrease in the global sorghum price in response to the decline in Chinese imports. The result of this scenario shows that the global sorghum price decreased by $13.34 \%, 9.59 \%$, and $5.8 \%$ for the first three years after the shock, respectively. The U.S., Argentina and Australia sorghum exports decreased by $17.58 \%, 26.38 \%$ and $9.76 \%$, respectively after the shock. Simultaneously, sorghum imports from Japan and Mexico increased by $2.8 \%$ and $46.26 \%$, respectively. 
TABLE 2

SCENARIO TWO WITH CHINA SORGHUM IMPORTS RESTRICTED

\begin{tabular}{|c|c|c|c|c|c|}
\hline \multicolumn{6}{|c|}{ Scenario Two with China Sorghum Imports Restricted } \\
\hline Commodity/Countries & \multicolumn{5}{|c|}{$\begin{array}{l}\text { Difference from the baseline projection in percent change } \\
\text { and } 1,000 \text { metric tons }\end{array}$} \\
\hline Sorghum & $2018 / 19$ & $2019 / 20$ & $2020 / 21$ & $2023 / 24$ & $2026 / 27$ \\
\hline $\begin{array}{l}\text { World price } \\
\text { Importers }(\%)\end{array}$ & $-7.40 \%$ & $-8.76 \%$ & $-8.30 \%$ & $-6.45 \%$ & $-3.29 \%$ \\
\hline China & $-27.18 \%$ & $-45.75 \%$ & $-60.25 \%$ & $-83.61 \%$ & $-91.75 \%$ \\
\hline Mexico & $25.66 \%$ & $30 \%$ & $29.48 \%$ & $18.54 \%$ & $8.24 \%$ \\
\hline Japan & $1.46 \%$ & $1.68 \%$ & $1.63 \%$ & $1.26 \%$ & $0.68 \%$ \\
\hline Exporters $(\%)$ & & & & & \\
\hline United States & $-9.38 \%$ & $-15.60 \%$ & $-21.23 \%$ & $-23.65 \%$ & $-16.83 \%$ \\
\hline Argentina & $-14.66 \%$ & $-21.58 \%$ & $-24.49 \%$ & $-21.69 \%$ & $-12.18 \%$ \\
\hline Australia & & & & & \\
\hline Importers $(1,000 \mathrm{mt})$ & & & & & \\
\hline China & -881 & -1294 & -1512 & -1396 & -838 \\
\hline Mexico & 231 & 287.6 & 298.1 & 248.4 & 134.6 \\
\hline Japan & 10.09 & 11.75 & 11.4 & 8.67 & 4.67 \\
\hline Exporters $(1,000 \mathrm{mt})$ & & & & & \\
\hline United States & -429.1 & -673.6 & -862.9 & -870.9 & -555.6 \\
\hline Argentina & -81.2 & -113.5 & -129 & -106.5 & -60.4 \\
\hline Australia & -53.1 & -101.4 & -104.9 & -81.4 & -42.8 \\
\hline
\end{tabular}

Source: USDA-Foreign Agriculture Service (FAS), Production, Supply and Distribution (PS\&D), 2017.

USDA-OCE-WAOB, USDA Agricultural Projections to 2026, Long-term Projections Report OCE-2017-1, February 2017.

For scenario two, as expected, the global sorghum price decreased, and sorghum exports increased for major exporters (U.S., Argentina, Australia). As shown in Table 2, the results of scenario two show that the global sorghum price decreased by $7.4 \%, 8.76 \%$, and $8.3 \%$ for the first three respective years following the shock compared to the baseline. Sorghum exports from the U.S., Argentina and Australia decreased by $9.38 \%, 14.66 \%$ and $5.44 \%$ respectively for the first year after the shock. Simultaneously, sorghum imports from Japan and Mexico increased by $1.46 \%$ and $25.66 \%$ respectively. For scenario three, as expected, the model simulation results show a decrease in the global sorghum price and trade. The results of scenario three show that the global sorghum price decreased by $18.3 \%, 17.38 \%$, and $11.9 \%$ respectively for the first three years after the shock. Sorghum exports from the U.S., Argentina and Australia decreased by $25.04 \%, 36.16 \%$ and $13.36 \%$ respectively for the first year after the shock. Simultaneously, Sorghum imports from Japan and Mexico increased by $4.07 \%$ and $63.49 \%$ respectively.

\section{China's Domestic Corn Market Impacts}

For scenario one, as expected, the model simulation results show an increase in China's domestic corn price in response to the decline in sorghum imports, a feed substitute for corn. China's domestic corn price increased slightly by $0.46 \%, 0.58 \%$, and $0.50 \%$ respectively for the first three years after the shock. Then the increase rate of China's corn price gradually dropped to almost zero as time progresses. China's corn planting area increased a small amount, which is $0.05 \%, 0.11 \%$, and $0.17 \%$ for the first three years following the shock, respectively. For scenario two, as expected, China's corn price increased after the shock. The result of scenario two shows that China's domestic corn price increased by $0.25 \%$ for the first year after the shock, and it increased by $0.53 \%, 0.75 \%, 0.89 \%$ for the following years respectively. 
China's corn planting area increased slightly, which is $0.02 \%, 0.08 \%$ and $0.17 \%$ for the first three years respectively. As expected, the model simulation results show an increase in China's domestic corn market. For scenario three, the results show that China's domestic corn price increased by $0.64 \%$ for the first year after the shock, and it increased by $1.12 \%, 0.96 \%, 0.78 \%$ for the following years respectively. China's corn planting area increased slightly, which is $0.07 \%, 0.20 \%$ and $0.30 \%$ for the first three years respectively.

\section{China's Domestic Pork and Poultry Market Impacts}

As expected, the model simulation results show a price increase in China's domestic pork and poultry markets. All three scenarios results showed that for both Chinese pork and poultry, price changed slightly for the first year after the shock and then increased a small amount through 2027. The results indicate that China's feed companies substituted corn for sorghum for feed use as a result of the sorghum import restriction in the scenarios and rising domestic sorghum prices described above.

\section{Results by Scenario}

The results of the scenarios all showed significant impacts toward China's sorghum imports. Figure 4 shows the comparison among the USDA-ERS baseline projection and all three scenarios.

\section{FIGURE 4 \\ THE BASELINE PROJECTION AND THREE SCENARIOS FOR CHINA'S SORGHUM IMPORTS (MILLION METRIC TONS)}

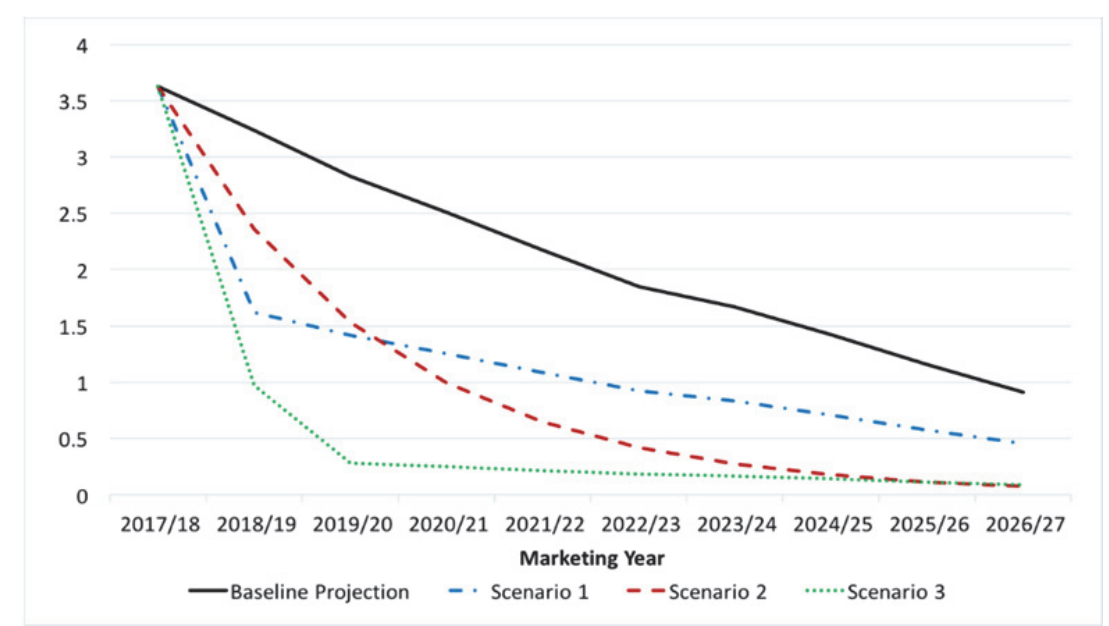

Source: USDA-Foreign Agriculture Service (FAS), Production, Supply and Distribution (PS\&D), 2017.

USDA-OCE-WAOB, USDA Agricultural Projections to 2026, Long-term Projections Report OCE-2017-1, February 2017.

For scenario one, the $50 \%$ decrease in imports shock, imposed significant impacts on both China's sorghum food consumption ( $21.51 \%$ decline) and sorghum feed demand ( $28.97 \%$ decline), global sorghum price $(13.34 \%$ decline), and China's sorghum stocks $(45.63 \%$ decline) for the first year following the shock in MY 2017/18. Afterwards, this decreasing rate for imports slowed compared to the baseline projection starting from year two. As for the major sorghum exporters, the U.S., Argentina and Australia, their sorghum exports decreased by $17.58 \%, 26.38 \%$ and $9.76 \%$ respectively after the shock. And as for the major sorghum importers, Japan and Mexico, their sorghum imports increased by $2.8 \%$ and $46.26 \%$ respectively.

For scenario two, the $35 \%$ decline in China's sorghum imports imposed significant impacts on China's sorghum food demand (11.69\% decline), sorghum feed demand (15.75\% decline), global 
sorghum price (7.4\% decline), and China's sorghum stocks $(24.8 \%$ decline) for the first year after the shock. Afterwards, the rate of decline for sorghum imports slowed for the subsequent years. Sorghum exports the U.S., Argentina and Australia decreased by $9.38 \%, 14.66 \%$ and 5.44\% respectively for the first year after the shock. Mexico's sorghum imports increased by $25.66 \%$. Japan's sorghum imports did not increase by a significant amount in the first year in scenario two.

For scenarios three, a 70\% decrease of sorghum imports from the USDA-ERS's baseline projection in year one and $90 \%$ in all subsequent years, impacts affected China's sorghum food demand $(30.12 \%$ decline), sorghum feed demand (40.56\% decline), global sorghum price (18.3\% decline), and China's sorghum stocks $(63.88 \%$ decline) significantly in the first year. After the first two years of the shock, the rate of decline for sorghum imports decreased to a very low level for the following years and sorghum was rarely imported by China. Sorghum exports for the U.S., Argentina and Australia decreased by $25.04 \%, 36.16 \%$ and $13.36 \%$ respectively for the first year after the shock. Mexico's sorghum imports increased by $63.49 \%$ for the first year. Again, Japan's sorghum imports did not increase by a significant amount in scenario three.

\section{DISCUSSION}

From China's domestic sorghum market perspective, as predicted, the results show that both China's sorghum food and feed demand decreased significantly in all three scenarios as sorghum imports declined and China substitutes corn for sorghum. Also, China's domestic sorghum price increased dramatically in all three scenarios because China cut its sorghum imports. Simultaneously, China's sorghum planting areas and production increased as well in response to the higher sorghum price. Given that sorghum and corn are substitutes, as the price of sorghum increased, the demand for corn also increased, thereby increasing the price of corn in the short term. The results also show that the price of poultry and pork increased slightly in China's domestic market with an increased sorghum price for the reason that sorghum demand is a derived demand for pork and poultry.

From the U.S. and the global sorghum market perspective, as predicted, the decrease of China's sorghum imports resulted in less sorghum demand and lower sorghum price in the global market. Sorghum exports for U.S. and other major sorghum exporters (Australia, Argentina) decreased significantly. However, sorghum imports increased significantly for Mexico.

In the long run, for both scenario two and scenario three, China's sorghum imports returned to the previous level (zero) prior to the policy shock as the corn price in China ultimately fell. The rate of China's sorghum imports declined faster in scenario three than that of scenario two. However, scenario two shows a gradual change of sorghum imports.

In terms of the simulation results, U.S.-China sorghum trade is a temporary success story, and it is risky for those U.S. sorghum exporters who rely on China's sorghum market. The results show the necessity to seek new sorghum export opportunities worldwide for U.S. sorghum exporters. Meanwhile, U.S. sorghum exporters may change their cropping patterns to continue making profits by switching out of sorghum.

\section{SUMMARY AND CONCLUSION}

The beginning and current sorghum story stems from changes in China's corn policy in 2008 because corn and sorghum are feed substitutes. In 2013, China's initial higher domestic corn price resulted in higher sorghum demand with a relatively lower price as a feed substitute. Prior to this, China implemented a corn temporary reserve program and a price support policy in 2008 nationwide to guarantee national food security and increase rural incomes. The Chinese government purchased corn from farmers at a minimum support price and accumulated corn in national storage facilities as stocks. The Chinese corn support price increased each year, which further encouraged corn production. This policy increased corn stockpiles and distorted the market with a high corn price (Wu and Zhang, 2016). Due to the higher domestic corn price, domestic corn consumption decreased significantly, and China 
started to import feed substitutes for corn; thus, sorghum imports started to increase. This is the temporary U.S. sorghum export success story.

The U.S. is the largest feed sorghum producer and exporter in the global sorghum market. In MY 2012/13, the U.S. accounted for 70\% of total global sorghum exports (Tran et al., 2015). In addition, U.S. sorghum has a lower price and a lower tannin content, which is more suitable for feed use compared to other countries' sorghum, such as Australia and Argentina. Due to the increased demand of China's sorghum imports, the U.S. became a major sorghum exporter to China in marketing year (MY) 2012/13. From the global sorghum importer perspective, In MY 2014/15, China's sorghum imports accounted for $84 \%$ of the world total sorghum imports, which indicates China's sorghum imports occupy an important place in global sorghum trade.

Changes in China's corn policy in 2016 once again affected the global sorghum market. China terminated its corn temporary reserve program and price support policy in 2016. Instead, China implemented a direct payment subsidy policy for corn, which is tied to corn planting acres (Wu and Zhang, 2016). This change of China's corn policy resulted in a lower Chinese domestic corn price, which increased corn demand. Thus, the demand for sorghum, which is one of most important corn substitutes for feed use, decreased significantly afterwards.

Figure 4 shows the comparison among the baseline projection and the three scenarios for China's sorghum imports. For the baseline projection, we found a steady decline of China's sorghum imports, and the imports is projected to decline to less than 1 MMT in MY 2026/27. For scenario one, after a significant shock, which is a $50 \%$ decrease in China's sorghum imports, the rate of decline remained steady but at a lower level for the following years up until MY 2026/27. China's sorghum imports are projected to decrease to less than 0.5 MMT. For scenario two, which is sorghum imports decreased by $35 \%$ each year from the previous year, the decrease rate kept decreasing as time goes by and China's sorghum imports finally reached almost zero in this scenario. For scenario three, China's sorghum imports declined tremendously for the first two years after the policy shock, and the import level remained at a low level afterwards. Imports finally go to zero as time progresses.

All three scenarios showed the risks of significant decline for both global sorghum prices and trade volumes stemming from the change of China's corn policy. The scenarios also showed a significant decline of U.S. sorghum exports. This result is a reminder for U.S. sorghum exporters that it is important to diversify cropping patterns to hedge potential risks, and it is necessary to seek new sorghum export opportunities worldwide.

However, there are some positive indications in the results as well. For example, Mexico ranks as the second largest sorghum importer in the world in 2016, and its sorghum imports increased by $46.26 \%$, $25.66 \%$ and $63.49 \%$ respectively for the first year after the policy shock in all three scenarios. This indicates a new market opportunity for U.S. sorghum exporters. U.S.-Mexico sorghum trade could become a new success story if U.S. sorghum exporters could seize this opportunity.

\section{ACKNOWLEDGEMENT}

Funding for this work was provided in part by the Agriculture and Food Research Initiative of the U.S. Department of Agriculture National Institute of Food and Agriculture, USDA-NIFA-AFRI Grant \#2014-67023-21946, "Expanding U.S. Market Access in China's Evolving Agricultural and Trade Policy Environment," the Virginia Agricultural Experiment Station and the Hatch Program of USDA-NIFA. The authors are grateful to our China research team members James Hansen, Francis Tuan, Agapi Somwaru and to Department Head Matt Holt for their support. The views expressed here are those of the authors and do not represent those of the Economic Research Service or the U.S. Department of Agriculture. 


\section{REFERENCES}

China Politics. (2016, March 29). Inventory Pressure Corn Price Mechanism in China to Market Pricing the Price. News Hub of Golden BRIC.

Food and Agriculture Organization (FAO) of the United Nations. (2014). Improving Feed Use Estimations: Data, Methodologies and Challenges. Agriculture Market Information System Scoping Study. Retrieved from http://www.amis-outlook.org/resources-list/detail/en/c/294276/

Gale, F. (2013, August). Growth and Evolution in China's Agricultural Support Policies. ERR-153. U.S. Department of Agriculture, Economic Research Service (USDA-ERS). Retrieved from https://www.ers.usda.gov/webdocs/publications/45115/39368_err153.pdf?v=41491

Gale, F. (2015, November). Development of China's Feed Industry and Demand for Imported Commodities. FDS-15K-01. USDA-ERS. Retrieved from https://www.ers.usda.gov/webdocs/publications/36929/55490_fds-15k-01.pdf?v=42327

Hansen, J., Gale, F., Marchant, M., Tuan, F., Zhong, F., Chen, W., \& Somwaru, A. (2015, July 26-28). Difficulties in Determining the Future of China's Commodity Trade: Policy Issues and Grain Production. Poster presented at the 2015 Agricultural \& Applied Economics Association and Western Agricultural Economics Association Joint Annual Meeting. San Francisco, CA, U.S. Retrieved from http://purl.umn.edu/205436

Hansen, J., Marchant, M.A., Zhang, W., \& Grant, J. (2018). Upheaval in China's Imports of U.S. Sorghum. Choices, Quarter 2. Retrieved from http://www.choicesmagazine.org/choicesmagazine/theme-articles/us-china-trade-dispute-and-potential-impacts-to-agriculture/upheaval-inchinas-imports-of-us-sorghum

Hansen, J., Tuan, F., \& Somwaru, A. (2011). Do China's Agricultural Policies Matter for World Commodity Markets? China Agricultural Economic Review. Emerald Group Publishing Limited, $3(1), 6-25$.

Hansen, J., \& Gale, F. (2014). China in the Next Decade: Rising Meat Demand and Growing Imports of Feed. USDA-ERS. April 2014. Retrieved from http://purl.umn.edu/211199

Hansen, J., Marchant. M.A., Tuan, F., \& Somwaru, A. (2017). U.S. Agricultural Exports to China Increased Rapidly Making China the Number One Market. Choices, 2nd Quarter. Retrieved from http://www.choicesmagazine.org/choices-magazine/theme-articles/us-commodity-marketsrespond-to-changes-in-chinas-ag-policies/us-agricultural-exports-to-china-increased-rapidlymaking-china-the-number-one-market

Hejazi, M., \& Marchant, M.A. (2017). China’s Evolving Agricultural Support Policies. Choices, 2nd Quarter. Retrieved from http://www.choicesmagazine.org/choices-magazine/theme-articles/uscommodity-markets-respond-to-changes-in-chinas-ag-policies/chinas-evolving-agriculturalsupport-policies

Liu, H., \& Zhou, X. (2016, November 11). Sorghum Trade Situation and Growing Trend. Agricultural Outlook. Shanghai Agricultural Bureau.

Marchant, M.A. (2017). Theme Overview: U.S. Commodity Markets Will Respond to Changes in China's Ag Policies. Choices, 2nd Quarter. Retrieved from

http://www.choicesmagazine.org/choices-magazine/theme-articles/us-commoditymarkets-respond-to-changes-in-chinas-ag-policies

Marchant, M.A., \& Wang, H.H. (2018). Theme Overview: U.S.-China Trade Dispute and Potential Impacts on Agriculture. Choices, Quarter 2. Retrieved from http://www.choicesmagazine.org/choices-magazine/theme-articles/us-china-tradedispute-and-potential-impacts-to-agriculture

Ministry of Agriculture of the People's Republic of China. (2017, January). China's Sorghum Market Condition in 2016 and 2017 Outlook. Ministry of Agriculture of the People's Republic of China. Retrieved from http://www.moa.gov.cn/zwllm/jcyj/201701/t20170122_5461513.htm 
Pindyck, R., \& Rubinfeld, D. (1981, January). Econometric Models and Economic Forecasts. McGrawHill.

Polansek, T. (2019, March 7). China Makes Biggest U.S. Sorghum Purchase since Trade War Began.” CNBC Reuters. Retrieved from https://www.reuters.com/article/us-usa-trade-chinasorghum/china-makes-biggest-us-sorghum-purchase-since-trade-war-beganidUSKCN1QO2DG

Sagami, T. (2011, July). China's Transformation into a Consumer-Driven Economy. Money and Markets. Tan, L., Wu, Z., Liu, M., Feng, Z., Hou, Y., \& Yang, W. (2015). Sorghum Application in Swine Feed. China Feed Industry Information. Retrieved from http://www.feedtrade.com.cn/technology/nutrition/ingredient/2015-02-03/2015749.html

Tran, A., Lee, T., Motamed, M., \& Hansen, J. (2015). China's Agricultural Policies Reshape Global Sorghum Trade. Amber Waves. USDA-ERS. Retrieved from https://www.ers.usda.gov/amberwaves/2015/june/china-s-agricultural-policies-reshape-global-sorghum-trade/

United States Department of Agriculture (USDA). (2015, November). Growth in U.S. Agricultural Exports to China. Press release No. 0325.15. Retrieved from https://www.usda.gov/media/pressreleases/2015/11/20/growth-us-agricultural-exports-china

USDA-Foreign Agricultural Service (USDA-FAS). (2014a). Sorghum Supply and Disappearance: Selected Exporters. Retrieved from www.fas.usda.gov

USDA-FAS. (2014b). World Sorghum Trade. Retrieved from www.fas.usda.gov

USDA-FAS. (2017). Production, Supply and Distribution (PS\&D Database). Retrieved from https://apps.fas.usda.gov/psdonline/app/index.html\#/app/home

USDA-National Agricultural Statistics Service (USDA-NASS). (2016, January). Crop Production 2015 Summary. ISSN: 1057-7823

USDA-Office of the Chief Economist (OCE), \& World Agricultural Outlook Board (WAOB). (2017, February). USDA Agricultural Projections to 2026. Long-term Projections Report OCE-2017-1.

Wang, H., \& Malaga, J. (2015, January 31-February 3). Assessing China's Potential Surge on Demand for Grain Sorghum. Selected paper presented at the Southern Agricultural Economics Association's 2015 Annual Meeting. Atlanta, Georgia. Retrieved from http://purl.umn.edu/196866

Wang, H., \& Malaga, J. (2016, February 6-9). What Would be the Corn and Sorghum Price Gap Allowing China to Continue Importing Sorghum? Selected paper presented at the Southern Agricultural Economics Association's 2016 Annual Meeting, San Antonio, Texas. Retrieved from http://purl.umn.edu/229887

Wu, Q., \& Zhang, W. (2016). Of Maize and Markets: China's New Corn Policy. Agricultural Policy Review. Center for Agricultural and Rural Development (CARD). Iowa State University.

Zhang, W. (2017). Simulation of Chinese Sorghum Imports from a New Perspective: U.S. and Global Impacts. M.S. Thesis, Agricultural and Applied Economics, Virginia Tech. 


\section{APPENDIX A \\ DESCRIPTION OF USDA-ERS CHINA MODEL — SORGHUM}

Demand

Demand $=$ Food demand + Feed demand

- Food demand $=$ Per capita food urban $\times$ Population urban + Per capita food rural $\times$ Population rural

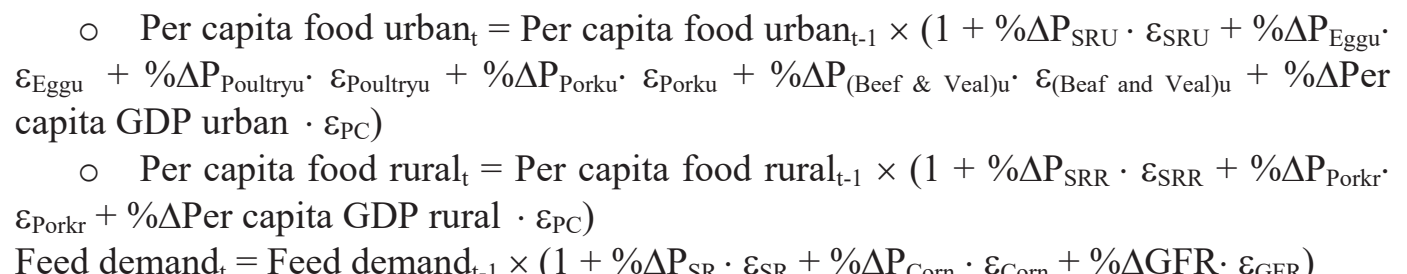

Supply

Supply $=$ Area harvested $\times$ Yield

- Area harvested $\mathrm{t}_{\mathrm{t}}=$ Area harvested $_{\mathrm{t}-1} \times\left(1+\% \Delta\right.$ Sorghum expected return $\cdot \varepsilon_{\mathrm{SER}}+\% \Delta$ Corn expected return $\cdot \varepsilon_{\mathrm{CER}}+\% \Delta$ Soybean expected return $\left.\cdot \varepsilon_{\mathrm{SER}}\right)$

- $\quad$ Yield $_{\mathrm{t}}=$ Yield $_{\mathrm{t}-1} \times\left(1+\% \Delta \mathrm{MA}_{\mathrm{SR}}\right)$

Imports

Imports $=$ Imports $_{\mathrm{t}-1} \times\left(1+\% \Delta \mathrm{Import}\right.$ price $\left.\cdot \varepsilon_{\mathrm{IP}}+\% \Delta \mathrm{Demand}_{\mathrm{Feed}} \cdot \varepsilon_{\mathrm{Feed}}\right)$

Stock Change

Stock Change $\mathrm{e}_{\mathrm{t}}=$ Stock change $_{\mathrm{t}-1} \times\left(1+\% \Delta \mathrm{P}_{\mathrm{FMP}} \cdot \varepsilon_{\mathrm{FMP}}\right)$

Variables

Demand

Demand: China's domestic demand for sorghum

Food Demand: China's domestic food demand for sorghum

Feed Demand: China's domestic feed demand for sorghum

Per capita food urban: Per capita food demand in urban area

Population urban: Population in urban area

Per capita food rural: Per capita food demand in rural area

Population rural: Population in rural area

$\% \Delta \mathrm{P}_{\mathrm{SRU}}$ : Percentage change of sorghum price in urban areas

$\varepsilon_{\mathrm{SRU}}$ : Own-price elasticity for sorghum food demand in urban areas

$\% \Delta \mathrm{P}_{\text {Eggu }}$ : Percentage change of egg price in urban areas

$\varepsilon_{\mathrm{Eggu}}$ : Cross-price elasticity between egg and sorghum food demand in urban areas

$\% \Delta \mathrm{P}_{\text {Poultryu: }}$ Percentage change of poultry price in urban areas

$\varepsilon_{\text {Poultryu: }}$ Cross-price elasticity between poultry and sorghum food demand in urban areas

$\% \Delta \mathrm{P}_{\text {Porku}}$ : Percentage change of pork price in urban areas

$\varepsilon_{\text {Porku}}$ : Cross-price elasticity between pork and sorghum food demand in urban areas

$\% \Delta \mathrm{P}_{(\text {Beef \& Veal) }}$ : Percentage change of beef \& veal price in urban areas

$\varepsilon_{\text {(Beaf and Veal)u }}$ : Cross-price elasticity between beef \& veal and sorghum food demand in urban areas

$\% \Delta$ Per capita GDP urban: Percentage change of per capita GDP in urban areas

$\varepsilon_{\mathrm{PC}}$ : Income elasticity of sorghum food demand in urban areas

Per capita food rural: Per capita food demand in urban area

$\% \Delta \mathrm{P}_{\mathrm{SRR}}$ : Percentage change of sorghum price in rural areas 
$\varepsilon_{\mathrm{SRR}}$ : Own-price elasticity for sorghum food demand in rural areas

$\% \Delta \mathrm{P}_{\text {Porkr }}$ : Percentage change of pork price in rural areas

$\varepsilon_{\text {Porkr }}$ : Cross-price elasticity between pork and sorghum food demand in rural areas

$\% \Delta$ Per capita GDP rural: Percentage change of per capita GDP in rural areas

$\varepsilon_{\mathrm{PC}}$ : Income elasticity of sorghum food demand in rural areas

Feed Demand: China's domestic feed demand of sorghum

$\% \Delta \mathrm{P}_{\mathrm{SR}}$ : Percentage change of domestic sorghum price

$\varepsilon_{\mathrm{SR}}$ : Own-price elasticity for sorghum feed demand

$\% \Delta \mathrm{P}_{\text {Corn }}$ : Percentage change of domestic corn price

$\varepsilon_{\text {Corn }}$ : Cross-price elasticity between corn and sorghum feed demand

$\% \Delta$ GFR: Percentage change of grain feeding requirement

$\varepsilon_{\mathrm{GFR}}$ : Elasticity of sorghum feed demand with respect to a change in the grain feeding requirement

Supply

Supply: China's domestic supply of sorghum

Area harvested: China's domestic sorghum harvested areas

Yield: China's domestic sorghum yield

$\% \Delta$ Sorghum expected return: Percentage change of sorghum expected returns

$\varepsilon_{\text {SER }}$ : Elasticity of sorghum harvested areas with respect to a change in the sorghum expected return

$\% \Delta$ Corn expected return: Percentage change of corn expected returns

$\varepsilon_{\mathrm{CER}}$ : Elasticity of sorghum harvested areas with respect to a change in the corn expected return

$\% \Delta$ Soybean expected return: Percentage change of soybean expected return

$\varepsilon_{\text {SER }}$ : Elasticity of sorghum harvested areas with respect to a change in the soybean expected return

$\% \Delta \mathrm{MA}_{\mathrm{SR}}$ : percentage change of three-year sorghum yields' moving average

Imports

Imports: China's sorghum imports from the global sorghum market

$\% \Delta$ Import price: Percentage change of China's sorghum import price

$\varepsilon_{\mathrm{IP}}$ : Price elasticity of China's sorghum imports

$\% \Delta$ Demand $_{\text {Feed: }}$ Percentage change of China's feed demand

$\varepsilon_{\text {Feed }}$ : Elasticity of China's sorghum imports with respect to a change in the China's feed demand

Stock Change

Stock Change: China's domestic sorghum stock change

$\% \Delta \mathrm{P}_{\mathrm{FMP}}$ : Percentage change of sorghum price

$\varepsilon_{\mathrm{FMP}}$ : Price elasticity of sorghum stock 


\section{APPENDIX B \\ BASELINE PROJECTED SORGHUM EXPORTS FOR SELECT COUNTRIES (UNITED STATES, ARGENTINA, AUSTRALIA)}

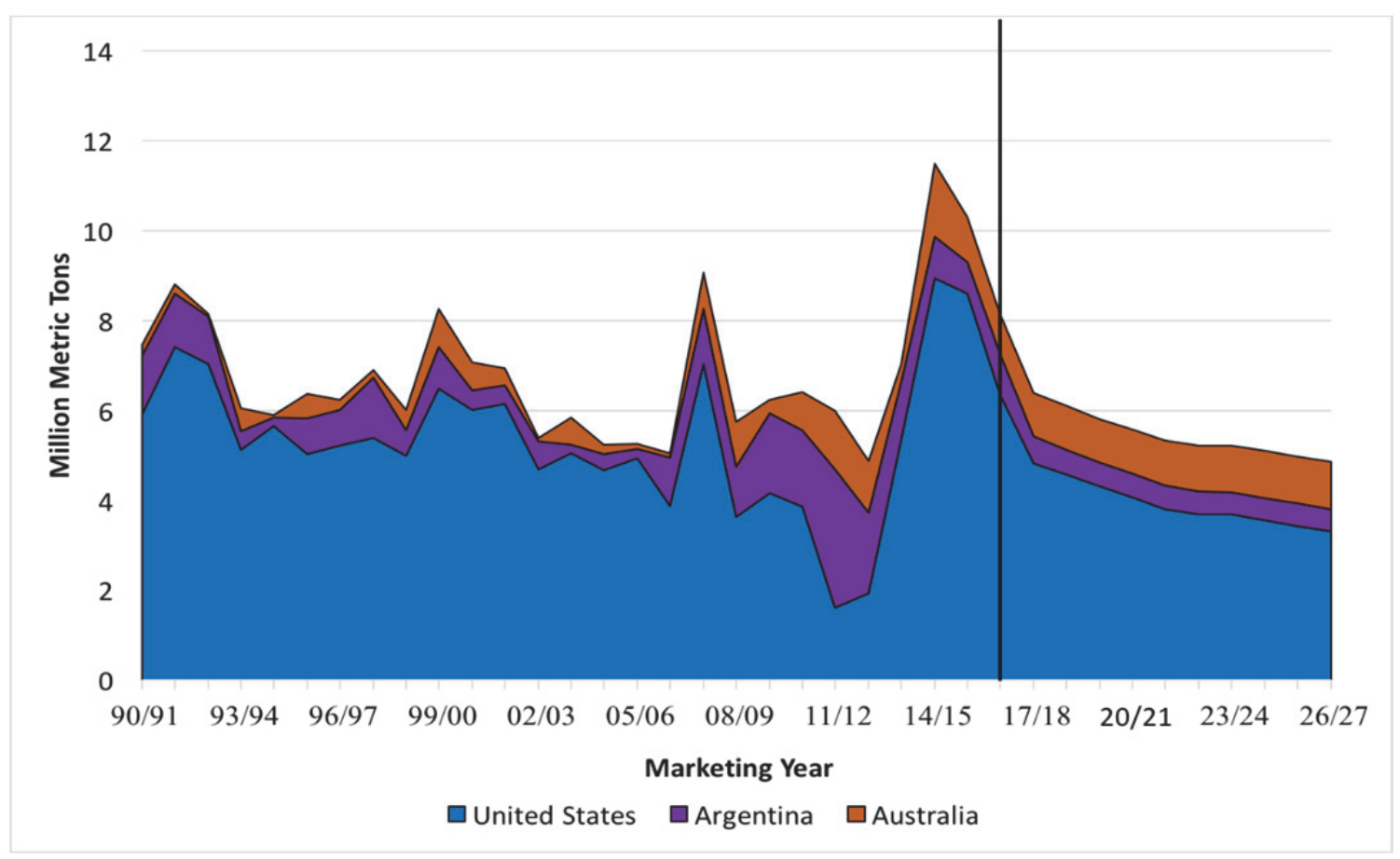

Source: USDA-Foreign Agriculture Service (FAS), Production, Supply and Distribution (PS\&D), 2017. USDA-OCE-WAOB, USDA Agricultural Projections to 2026, OCE-2017-1, February 2017. 